\title{
$\$$ Research Square

\section{EMFO based Supervision Kernel Entropy Component Analysis for High Speed Encrypted Transmission Model}

Babu M ( $\sim$ mbabu.phd@gmail.com )

R.M.K. College of Engineering and Technology

\section{Sathish Kumar G A}

Sri Venkateswara College of Engineering

Keywords:

Posted Date: June 2nd, 2021

DOI: https://doi.org/10.21203/rs.3.rs-554247/v1

License: (c) (i) This work is licensed under a Creative Commons Attribution 4.0 International License.

Read Full License 


\section{Abstract}

The authors have requested that this preprint be removed from Research Square. 